\title{
Stigma, discrimination, and HIV/AIDS knowledge among physicians in Barbados
}

\author{
Ernest Massiah, ${ }^{1}$ Timothy C. Roach, ${ }^{2}$ Carol Jacobs, ${ }^{3}$ Anne M. St. John, ${ }^{2}$ \\ Vashti Inniss, ${ }^{4}$ Jerome Walcott, ${ }^{4}$ and Chris Blackwood ${ }^{2}$
}

Suggested citation Massiah E, Roach TC, Jacobs C, St. John AM, Inniss V, Walcott J, Blackwood C. Stigma, discrimina-tion, and HIV/AIDS knowledge among physicians in Barbados. Rev Panam Salud Publica. 2004; 16(6):395-401.

ABSTRACT Objective. To determine the extent of clinical knowledge of HIV/AIDS that physicians in Barbados have and their attitudes towards persons living with HIV/AIDS.

Methods. In 2000 the Barbados Association of Medical Practitioners conducted a survey in order to assess its members' views on HIV/AIDS issues. Over a two-month period 203 physicians (76\% of all those practicing in the country) were interviewed. The survey included physicians working in private practice and the public sector. They were surveyed individually concerning their attitudes towards counseling as well as their clinical knowledge, perception of safe practices, fear of occupational exposure, views on ethical issues, experience treating HIV/AIDS patients, and background with HIV/AIDS continuing education.

Results. In comparison to physicians who had graduated in later years, physicians who had graduated in 1984 or earlier had seen fewer HIV/AIDS clients, had lower levels of knowledge about the disease, were more likely to test for HIV/AIDS without informed consent, and were less likely to have ever attended a continuing education training course on HIV/AIDS. Overall, knowledge of the clinical indications of HIV/AIDS was low, and $76 \%$ of the physicians did not think they had adequate counseling skills. Over $80 \%$ of the physicians were comfortable looking after HIV/AIDS patients. While 95\% of the physicians would not release HIV test results without a patient's consent, 33\% would test, without consent, a seriously ill patient, and $15 \%$ would test without consent a patient upon whom they had to perform an invasive procedure if they perceived the patient to be from a high-risk population such as gay men or commercial sex workers. Only 53\% of the physicians had attended an HIV/AIDS in-service training program between 1995 and 1999.

Conclusions. Physician training in Barbados should focus on all aspects of HIV/AIDS care, including clinical and emotional factors. Attendance at such training should be mandatory for public sector physicians, and medical school curricula need to be examined to ensure their HIV/AIDS content is current and comprehensive.

Keywords Attitude of health personnel; HIV infections; acquired immunodeficiency syndrome; education, medical; inservice training; prejudice; Barbados.

1 Inter-American Development Bank, Washington, D.C., United States of America. Send correspondence to: Ernest Massiah, Inter-American Development Bank, 1300 New York Ave., N.W., Washington, D.C. 20577, United States of America; e-mail: Ernestm@iadb.org
2 Barbados Association of Medical Practitioners, Bridgetown, Barbados.

3 Barbados National AIDS Commission, Bridgetown, Barbados.

4 Ministry of Health, Bridgetown, Barbados.
Greater access to antiretroviral medications will increase the demands placed on physicians to provide treatment and counseling to HIV-positive 
patients. Physicians must have appropriate knowledge of treatment regimens and their side effects, and they must be able to provide responsive and client-friendly services to a wide range of patients, some of whom will be from sexual minorities or subpopulations that have been traditionally stigmatized or marginalized such as transgendered persons, bisexual or gay men, and commercial sex workers

Over the last decade various studies have been conducted with physicians, nurses, medical students, dentists, and dental assistants in developed and developing countries to assess the knowledge, attitudes, and behaviors of providers who interact with persons with HIV / AIDS (1-5). One difficulty with these surveys has been their approach to sampling, and the response rates obtained. Response rates have ranged from $85 \%$ to $29 \%$, with lower rates observed for mail surveys $(1,6)$. In developing countries few surveys have been able to collect data from a representative sample of all registered and/or practicing physicians, especially those in private practice. Most studies have collected data from selected hospitals or clinics or relied on responses from mail surveys. A second concern is that the majority of surveys have focused on measuring cognitive knowledge and not on the emotional dimensions of working with persons with HIV/ AIDS and how stigma and discrimination influence providers' willingness to be involved in the clinical management of HIV / AIDS patients.

The knowledge and attitudes of medical practitioners are related to the social context of the epidemic and the level of HIV prevalence. In lowprevalence areas and where opportunities for in-service training are limited, physicians are likely to perceive themselves as lacking the skills needed to manage HIV/AIDS patients (7). In developed countries, as more information about HIV/AIDS has become available to patients and physicians and broad antidiscrimination legislation has been enforced, the demand for tests, counseling, and treatment has increased. Physicians are required to provide specific information to HIV/
AIDS patients and to customize it for a wide range of client needs (8). In these contexts, physicians have become more comfortable discussing HIV/ AIDS issues with their patients and have higher levels of knowledge about HIV / AIDS $(6,9)$.

However, in both developed and developing countries, physicians have common concerns and behaviors. Health staff are worried about occupational exposure (10-13), and they often have high levels of anxiety and fear when dealing with HIV-positive persons $(6,8)$. Some physicians may overestimate their risk exposure and so become overly cautious in low- or norisk situations $(13,14)$, while those in high-risk situations may take too few precautions (12).

Approaches to counseling vary among physicians. Many do not counsel clients about the need for HIV testing, and many do only limited pre- or posttest counseling (2). Based on their perceptions of who is likely to have HIV / AIDS, some physicians have administered HIV/AIDS tests without obtaining patient consent (15).

HIV/AIDS knowledge levels are varied among health personnel $(10,16$, 17). In settings where there are low levels of knowledge about HIV / AIDS and where few precautionary measures are taken, such as the use of gloves and the avoidance of contact with bodily fluids, health personnel are likely to believe that they are not prepared to care for persons with HIV / AIDS (14).

Some physicians discriminate against persons with HIV / AIDS, including by refusing to have them in their practice (17-20). Although physicians may feel an ethical obligation to treat persons with HIV / AIDS, this does not always indicate a willingness to do so if they are able to choose otherwise (1-2). While some physicians cite a lack of time to treat such patients (18), their hesitance more likely hints at an underlying fear of occupational risk and at discrimination against persons with HIV / AIDS based on the patients' sexuality, gender, or illegal behaviors. Physicians' responses may also reflect a calculated business decision. Having patients with HIV / AIDS can stigmatize a practice and lead to a reduced patient load and a loss in income (17).

The stigma associated with HIV/ AIDS is not one dimensional. Rather, it involves a variety of overlapping stigmas, many of which predate the HIV / AIDS epidemic (21). Reactions to people with HIV / AIDS vary according to their age, gender, sexual orientation, and mode of transmission. Unfortunately, notions of innocence and guilt are still part of many societies' conceptualization of HIV/AIDS. The "innocent case," such as a child born HIVpositive, provokes societal responses that are different from those for a stereotypically "guilty case" such as a gay man in a nonmonogamous relationship. Providers have not been immune from those reactions. Women with HIV / AIDS do not face the stigma of sexual orientation, but young women face the issue of "culpable promiscuity," where they are blamed for being sexually active and not being chaste. Young boys evade this stigma, as they are expected to be sexually active, but they may endure questions about their sexual preference (22). The stigma associated with being from one of the marginalized populations associated with HIV/AIDS, in particular being gay (20), and the belief that $\mathrm{HIV} /$ AIDS is associated with promiscuous sexual behavior or illegal behaviors, such as drug use (16), have shaped providers' willingness to interact with HIV / AIDS patients.

HIV / AIDS has forced physicians to confront their perceptions of sexuality, especially homosexuality. Religious and moral beliefs about homosexuality influence physicians' knowledge and their attitudes towards working with persons with HIV/AIDS (5, 6, 23). Physicians who are not comfortable interacting with gay men or drug users do not want them in their practice $(17,18)$. HIV / AIDS has also required physicians to become more comfortable taking sexual histories and being able to understand and interpret risk for their patients. However, either because they were not trained to do so or they are embarrassed, many physicians do not regu- 
larly obtain sexual histories from clients. Many physicians also do not discuss high-risk behaviors, including homosexual acts, even when patients have symptoms suggesting HIV/ AIDS (24).

Generally, health care settings with high levels of fear and discriminatory practices have few measures in place to reduce the risk of occupational exposure as well as no management protocols and policy guidelines for dealing with HIV/AIDS (7). The survival rate for HIV/AIDS patients is higher among practitioners with more experience in HIV/AIDS management (6). Physicians with broad HIV/AIDS knowledge and strong counseling skills often have had prior training on HIV / AIDS (25), have been exposed to informal peer education (19), or are recent medical graduates (9).

Training on the emotional aspects of working on HIV/AIDS is important. Early training initiatives sought to provide physicians with cognitive knowledge about transmission, clinical symptoms, and drug therapies. Little of the training focused on the emotional and psychosocial skills that physicians need to work with HIV/ AIDS patients. HIV / AIDS is still linked to a variety of social stigmas and discriminatory practices, Physicians need educational programs that make them more aware of how their prejudices affect clients' health-seeking behavior and that also provide the physicians with the skills needed to work with people with HIV / AIDS.

The AIDS epidemic has grown in Barbados since the first case was identified in the country in 1984. By June 2001 there were over 2600 cases of HIV / AIDS identified and over 1100 deaths. As in the rest of the Caribbean, the epidemiological profile of the disease has changed. Homosexual transmission is no longer the main cause of infection, and females account for one of every three cases. While heterosexual transmission is a major infection route, male patients still face the stigma associated with homosexuality, and the disease is still associated with shame, promiscuity, and immoral or illegal sexual behaviors.
There are few published studies on Caribbean health care workers' knowledge about HIV/AIDS and their behavior towards people with HIV/ AIDS. A survey of medical students in Barbados in the mid-1990s showed that they were uncomfortable with issues related to homosexuality and would prefer not to treat gay men with HIV / AIDS (26). Research in Jamaica demonstrated that in-service education programs had been successful in improving physicians' clinical management skills (27).

This paper presents the results of a survey that the Barbados Association of Medical Practitioners (BAMP) conducted among its members in the year 2000. The objectives of the survey were to examine physicians' clinical knowledge about HIV/AIDS and their attitudes towards persons with HIV/ AIDS as well as to identify the types of related education programs that BAMP should develop for its members.

\section{DESIGN AND METHODS}

Barbados has a population of 250000 and approximately 270 practicing physicians. The Barbados Association of Medical Practitioners is a professional organization and representative trade union of physicians who practice in the country. To practice medicine in Barbados, physicians do not have to be members of BAMP. However, traditionally most, if not all, physicians in the country are members of the association. At the time of the survey the BAMP had 350 members. During a sixweek period in August and September 2000, BAMP's AIDS Task Force conducted a survey of the BAMP membership.

Six interviewers were trained for two days before conducting the survey. The survey instrument was pilottested on physician members of the BAMP AIDS Task Force (who were excluded from the study) and on nurses involved in AIDS clinical management in the public sector. The interviewers were managed by a field research coordinator, who ensured quality control. The quality control process did not change answers or responses but instead ensured that nonresponses and unclear answers were identified prior to data entry.

Of the 350 registered BAMP members, only 267 of them were practicing medicine at the time of the survey. Interviews were secured with 203 (76\%) of the 267. The majority of the nonrespondents were out of the country on holiday, and interviews could not be arranged with 8 to 10 physicians who worked exclusively in private practice.

Physicians were asked about their attitudes towards counseling, knowledge of $\mathrm{HIV} / \mathrm{AIDS}$ diagnosis and treatment, perceptions of safe sex behaviors, fear of occupational exposure, experience treating persons with HIV / AIDS, and their formal education on HIV/AIDS issues. The questionnaires were administered individually at the physicians' offices in the main hospital, primary health care facilities, and their private practices. The data were subjected to univariate and bivariate analyses to detect significant differences between scores. Scales were developed using principal components factor analysis.

\section{RESULTS}

Of the 203 physicians interviewed, $135(67 \%)$ were men and 68 (33\%) were women. The analysis in this paper is based on this sample of 203 physicians. Of the physicians interviewed, $45 \%$ of them were practicing in a public sector hospital, and 7\% at a primary health care facility; $45 \%$ were in private practice; and $3 \%$ declined to state their primary place of practice.

Disaggregated by year of graduation, $43 \%$ of the physicians had graduated in 1984 or before, $15 \%$ between 1985 and 1989, 13\% between 1990 and 1994 , and $29 \%$ in the period of $1995-$ 1999. Thus the single largest group (43\%) had graduated in 1984 or before, when HIV/AIDS was not likely to have been part of the medical school curriculum. Almost all the physicians who had graduated in 1995-1999 worked in public sector facilities, while $71 \%$ of physicians who gradu- 
TABLE 1. Physicians' place of medical practice and the number of HIV/AID patients ever seen, Barbados, 2000

\begin{tabular}{ccc}
\hline $\begin{array}{l}\text { No. of HIV/AIDS } \\
\text { patients ever seen }\end{array}$ & $\begin{array}{c}\text { Private sector } \\
\text { physicians (\%) }\end{array}$ & $\begin{array}{c}\text { Public sector } \\
\text { physicians (\%) }\end{array}$ \\
\hline None & 4 & 1 \\
$1-3$ & 11 & 9 \\
$4-6$ & 17 & 12 \\
$7-9$ & 10 & 7 \\
$10+$ & 58 & 71 \\
Total & 100 & 100 \\
\hline
\end{tabular}

ated in 1984 or before worked in private practice. Over the last 20 years in Barbados there has been a change in the gender profile of the physicians: $77 \%$ of the physicians surveyed who had graduated in 1984 or earlier were male, but $59 \%$ of those in the 19951999 cohort were female.

The majority of the physicians, particularly those working in the public sector, have attended to patients with HIV/AIDS. Just over $70 \%$ of public sector physicians have attended to 10 or more HIV/AIDS patients in the course of their career, compared to $58 \%$ of physicians in private practice (Table 1).

Physicians who had graduated in 1984 or before had seen significantly fewer HIV/AIDS patients than had the physicians who had graduated in the period of 1995-1999 $(P<0.05)$ (Table 2). Among physicians who had graduated in 1984 or before, $51 \%$ of them had seen 10 or more patients with HIV/AIDS over their career. In contrast, $72 \%$ of the physicians who graduated in the 1995-1999 period had seen 10 or more HIV/AIDS patients. The gender of the provider did not significantly influence the number of patients seen.

Attitudes toward persons with HIV/AIDS varied among the physicians interviewed. Only 3\% of the physicians would rather not have persons with HIV / AIDS in their practice, and $82 \%$ stated they would have no problem attending to persons with HIV/AIDS. Physicians' attitudes towards treating HIV/AIDS patients were influenced by caseload: Physicians who had attended to 9 or fewer HIV/AIDS patients in their career were less likely to feel comfortable than were physicians who had attended to 10 or more patients in their career $(P<0.05)$. Only $4 \%$ of the sample felt that physicians with HIV/ AIDS should be barred from practicing medicine. Over $95 \%$ of the physicians said they would not disclose, without consent, a patient's HIV status to a patient's relative or partner or to

TABLE 2. Physicians' year of graduation and their HIV/AIDS experience and knowledge, Barbados, 2000

\begin{tabular}{|c|c|c|c|c|c|}
\hline Variable & $\begin{array}{l}\text { All graduates } \\
\quad(n=203)\end{array}$ & $\begin{array}{c}\text { Graduation } \\
\leq 1984 \\
(n=88)\end{array}$ & $\begin{array}{c}\text { Graduation } \\
1985-1989 \\
(n=30)\end{array}$ & $\begin{array}{c}\text { Graduation } \\
1990-1994 \\
(n=26)\end{array}$ & $\begin{array}{c}\text { Graduation } \\
1995-1999 \\
(n=59)\end{array}$ \\
\hline \multicolumn{6}{|l|}{ Gender } \\
\hline Male (\%) & 66 & 77 & 87 & 65 & 41 \\
\hline Female (\%) & 34 & 23 & 13 & 35 & 59 \\
\hline \multicolumn{6}{|l|}{ Caseload } \\
\hline No problem attending to HIV/AIDS patients (\%) & 82 & 85 & 80 & 81 & 81 \\
\hline \multicolumn{6}{|l|}{ Physicians would perform HIV test without patient consent } \\
\hline $\begin{array}{l}\text { If patient seriously ill (\%) } \\
\text { In case of an invasive procedure and patient }\end{array}$ & 33 & 27 & 44 & 33 & 33 \\
\hline perceived to be in high-risk group (\%) & 15 & 22 & 17 & 4 & 10 \\
\hline \multicolumn{6}{|l|}{ HIV/AIDS knowledge } \\
\hline Clinical knowledge (scale, 0-11) (mean) & 6.8 & 6.4 & 6.5 & 7.7 & 7.1 \\
\hline \multicolumn{6}{|l|}{ HIV/AIDS in-service training } \\
\hline Attended course $(\%)$ & 74 & 49 & 86 & 83 & 82 \\
\hline Attended course in preceding $5 \mathrm{yr}(\%)$ & 53 & 41 & 47 & 54 & 73 \\
\hline
\end{tabular}


an insurance company. An equally high percentage said they would not give test results over the phone.

While most physicians would not perform an HIV test without consent on a person in prison or at an antenatal clinic, 32\% would test without consent if the patient were seriously ill. In addition, $15 \%$ would test a patient without consent if they had to perform an invasive procedure on that person and they suspected that that individual was from a high-risk group. This attitude was significantly related to the year of graduation. Compared to physicians who had graduated in 1985 or after, physicians who had graduated in 1984 or before were significantly more willing to perform HIV tests without consent $(P<0.01)$.

Fear of occupational exposure to HIV / AIDS was measured on a 5-point scale. Among the physicians surveyed $65 \%$ were not scared of occupational exposure to HIV/AIDS (scores of 4 and 5 on the scale), $25 \%$ were uncertain if they were at risk (score of 3 on the scale), and $10 \%$ were scared they could become infected (scores of 1 and 2). Physicians who had graduated in the 1995-1999 period were less likely to be scared of occupational exposure than were physicians who had graduated before $1995(P<0.01)$.

Over $90 \%$ of the physicians agreed that pretest counseling was necessary for allaying fears and for preparing patients to have an HIV test. However, $25 \%$ of physicians did not believe pretest counseling was necessary when identifying risk factors. Their thinking on posttest counseling was different: $16 \%$ did not believe it was always necessary after an HIV test, and $25 \%$ believed posttest counseling provided an opportunity to advise clients about the risks of promiscuity. While 39\% of all physicians felt they should be expected to provide some form of HIV/AIDS counseling, 15\% believed that they did not have the time to do so, $65 \%$ felt this was best done by trained counselors, and $76 \%$ did not think they had the skills required to provide this service. The attitudes concerning counseling were related to the number of HIV/AIDS patients that the physicians had attended to over the course of their career. Physicians who had attended to 10 or more patients felt more skilled counseling patients than did physicians who had seen 9 or fewer patients in their career $(P<0.05)$.

Knowledge of the clinical indications of AIDS was measured on an 11item scale (eigenvalue 2.75) that measured knowledge of the 1993 revision of the classification system for HIV infection of the Centers for Disease Control and Prevention of the Unites States (Table 2). The lowest score that any of the physicians surveyed received was 3 (three items answered correctly). However, $46 \%$ of all the physicians had scores of 6 or lower on this scale.

Knowledge of pediatric AIDS transmission and its symptoms was not high. Seventeen percent of physicians did not agree that transmission occurred in the perinatal period, $22 \%$ did not think a failure to thrive was characteristic of infants with HIV/AIDS, $56 \%$ did not think HIV / AIDS could be diagnosed in a child under the age of 18 months (because of the presence of positive maternal antibodies), and $58 \%$ agreed that one could inoculate an HIV-positive infant with the BCG vaccine.

Knowledge of how to prevent mother-to-child transmission was low. Forty-three percent of all the physicians were unsure when antiretrovirals should be given to pregnant women who were HIV-positive, and $48 \%$ did not know when and for how long antiretrovirals should be given to babies born to HIV-positive mothers.

All the physicians believed that engaging in unprotected anal and vaginal sex and having multiple partners were risky behaviors and would advise their clients to use a condom. However, there was uncertainty about oral transmission. Ninety percent of the physicians believed that kissing a person with AIDS was not a high-risk behavior, but $74 \%$ would advise their patients to avoid "deep kissing," and $31 \%$ believed that oral sex was risky. This uncertainty about oral transmission was reflected in doctors' opinions on mouth-to-mouth resuscitation: 50\% considered this a high-risk behavior.

Just under three-quarters of the physicians $(74 \%)$ had attended an HIV/AIDS training course over the period of 1985-2000. Among physicians who had graduated in or before $1984,49 \%$ had attended a course, compared to $82 \%$ for graduates from the 1995-1999 period. Fifty-three percent of all the doctors had attended a course in the 1995-1999 period. The lowest level of attendance at courses in this period was from graduates from 1984 and before, $41 \%$, compared to $47 \%$, $54 \%$, and $73 \%$ for physicians who had graduated in 1985-1989, 1990-1994, and 1995-1999, respectively. Overall, $32 \%$ of the male physicians had never attended a course on HIV / AIDS, compared to $16 \%$ of female physicians. Female physicians were also more likely to have attended a course in the 1995-1999 period than were the male physicians.

\section{DISCUSSION}

Within the last decade in the Caribbean, HIV/AIDS has profoundly changed the supply and demand for counseling and clinical services, and altered expectations of quality of care provided to persons with HIV/AIDS. In addition to being able to manage clinical information, physicians working with HIV / AIDS patients are forced to confront their own prejudices about the sexual and moral choices of persons whom they perceive to be at high risk or who have HIV/AIDS. At the same time, physicians are being asked to address the psychosocial needs of persons with HIV/AIDS in a "clientfriendly" manner.

The results of our survey in Barbados showed a cohort effect. Physicians who had graduated in 1984 or before made up $43 \%$ of all the physicians. In comparison to later graduates, they had seen fewer HIV / AIDS clients, had lower levels of knowledge about the disease, were more likely to test for HIV/AIDS without informed consent, and were less likely to have ever attended a continuing education train- 
ing course on HIV/AIDS. These findings raise serious questions about the quality of care being provided, especially as newer drug therapies become available and treatment regimens need to be changed. The survey did not ask clients about the quality of care received, but future research efforts should investigate their perceptions of service quality and its effect on their health-seeking behavior.

The new demands posed by HIV/ AIDS have important ramifications for the content of medical education in the Caribbean. Knowledge of pediatric AIDS, clinical manifestations, and transmission routes were low across all graduation cohorts. These findings suggest the need to upgrade the HIV / AIDS content in the medical curriculum at the regional university, the University of the West Indies, where the majority of physicians who work in the English-speaking Caribbean are trained. HIV/AIDS is one of the main causes of death and morbidity among those 24-45 years old in the Caribbean. The recent reductions in antiretroviral drug prices negotiated by Caribbean governments will increase access to treatment for the poor, most of whom use public health facilities. Medical school curricula need to be updated to provide physicians with the skills they will need to address the growing HIV / AIDS health care demands.

Approximately one-quarter of the physicians surveyed had not attended a training course on HIV/AIDS in the preceding 15 years. This may reflect both the demand and the supply of continuing medical education courses. Medical associations, such as BAMP, can develop government-endorsed in- service training programs for practicing physicians. However, unless the incentive structures are changed, participation in such courses will be volitional. At a minimum, in public facilities, where the majority of HIV/AIDS cases are seen and where complicated cases are referred, the right to practice should be linked to attendance at inservice training courses that address emerging health issues, including HIV / AIDS.

HIV/AIDS has transformed the role of counseling, which is now an important skill that must accompany the clinical interaction. While many of the physicians surveyed saw the need for counseling, they felt it was best done by trained counselors, and the majority believed they were inadequately trained to provide counseling or did not have the time to offer it. HIV/ AIDS has altered the role of the physician, particularly in resource-poor settings. Counselors are not always available in developing countries. At a minimum, physicians, particularly those working in the public sector health facilities, need to have basic counseling skills since the majority of HIV/AIDS cases are be likely to be seen in these facilities.

Some of the physicians in Barbados were still uncomfortable having HIV/AIDS clients, and others, when they felt at risk of occupational exposure, were willing to test patients for HIV/AIDS without informed consent. In Barbados and other Caribbean countries, gay men and commercial sex workers are perceived to be among the high-risk groups. There are behavioral stereotypes for each of these groups, and a history of exclusionary practices. For example, openly or suspected gay or bisexual men have been denied employment and housing; commercial sex work, homosexuality, and sodomy are illegal and prosecuted in some Caribbean countries; and gay men and sex workers are subject to acts of violence. Some physicians in Barbados have made assumptions about sexual behavior and health status based on individuals' physical appearance. This unfortunate "diagnostic approach" reflects prejudices that can prevent the provision of comprehensive, client-friendly care and counseling to sexually active patients and limit the utilization of services by persons with HIV/AIDS.

HIV/AIDS involves a variety of stigmas, in particular those dealing with sexuality. In addition to cognitive knowledge about treatment, prevention, and care, physician training should address the emotional aspects of working with persons with HIV/ AIDS, and with sexual subpopulations. The training should develop the skills and the tools to recognize and reduce fears about HIV / AIDS and about people with HIV/AIDS. This type of training would provide physicians with the skills needed to discuss sexual acts and varying forms of sexual expression. Physicians need to be made aware of their own prejudices and how these attitudes influence their behavior and their approach to patients. This is critical in contexts where there are entrenched stereotypes about sexuality and sexual practices and where there is no legislation to prevent discrimination against sexual minorities or there is limited enforcement of existing antidiscrimination laws.

\section{REFERENCES}

1. Chan R, Khoo L, Goh CL, Lam MS. A knowledge, attitudes, beliefs and practices (KABP) survey on HIV infection and AIDS among doctors and dental surgeons in Singapore. Ann Acad Med Singapore. 1997;26(5): 581-7.

2. Evans JK, Bingham JS, Pratt K, Carne CA. Attitudes of medical students to HIV and AIDS. Genitourin Med. 1993;69(5):377-80.

3. Konde-Lule JK, Musagara M, Musgrave S. Focus group interviews about AIDS in Rahai

District of Uganda. Soc Sci Med. 1993;37(5): 679-84.

4. Davidson G, Gillies P. Safe working practices and HIV infection: knowledge, attitudes, perception of risk and policy in hospital. Qual Health Care. 1993;2(1):21-6.

5. Passannante MR, French J, Louria DB. How much do health care providers know about AIDS? Am J Prev Med. 1993;9(1):6-14.

6. Mulvey G, Temple-Smith M. Managing people with HIV/AIDS- the involvement of Vic- torian general practitioners. Aust Fam Physician. 1997;26 Suppl 2:S66-70.

7. Fransman D, McCulloch M, Lavies D, Hussey G. Doctors' attitudes to the care of children with HIV in South Africa. AIDS Care. 2000; 12(1):89-96.

8. Ros CC, Kerssens JJ, Foets M, Peters L. Trends in HIV-related consultation in Dutch general practice. Int J STD AIDS. 1999;10(5):294-9.

9. Haas DM, Coe RM. Do physicians discuss HIV and AIDS with patients? A survey of 
physician practices. J Community Health. 1997;22(6):401-16.

10. Fusilier M, Manning MR, Santini Villar AJ, Torres Rodriguez D. AIDS knowledge and attitudes of health-care workers in Mexico. J Soc Psychol. 1998;138(2):203-10.

11. Biddlecom AE, LeClere FB, Hardy AM, Hendershot GE. National study of knowledge of AIDS, testing patterns, and self-assessed risk among health care workers. J Acquir Immune Defic Syndr. 1992;5(11):1131-6.

12. Storosum JG, Sno HN, Schalken HF, Krol LJ, Swinkels JA, Nahuijs M, et al. Attitudes of health care workers towards AIDS at three Dutch hospitals. AIDS. 1991;5(1):55-60.

13. Duyan V, Agalar F, Sayek I. Surgeons' attitudes toward HIV/AIDS in Turkey. AIDS Care. 2001;13(2):243-50.

14. Bishop GD, Oh HM, Swee HY. Attitudes and beliefs of Singapore health care professionals concerning HIV/AIDS. Singapore Med J. 2000; 41(2):55-63.

15. Boyd JS, Kerr S, Maw RD, Finnighan EA, Kilbane PK. Knowledge of HIV infection and AIDS, and attitudes to testing and counselling among general practitioners in Northern Ireland. Br J Gen Pract. 1990;40(333):158-60.

16. Khandwalla HE, Luby S, Rahman S. Knowledge, attitudes and practices regarding sexually transmitted infections among general practitioners and medical specialists in Karachi, Pakistan. Sex Transm Infect. 2000;76 (5):383-5.

17. Bredfeldt RC, Dardeau FM, Wesley RM, Vaughan-Wrobel BC, Markland L. AIDS: family physicians' attitudes and experiences. J Fam Pract. 1991;32(1):71-5.

18. Gerbert B, Maguire BT, Bleecker T, Coates TJ McPhee SJ. Primary care physicians and AIDS. Attitudinal and structural barriers to care. JAMA. 1991;266(20):2837-42.

19. Fournier PO, Baldor RA, Warfield ME, Frazier B. Patients with HIV/AIDS: physicians' knowledge, attitudes, and referral practices. J Fam Pract. 1997:44(1):85-9.

20. Krasnik A, Fouchard JR, Bayer T, Keiding N Health workers and AIDS: knowledge, attitudes and experiences as determinants of anxiety. Scand J Soc Med. 1990;19(4):103-13.

21. Aggleton P, Parker R, Maluwa M. Stigma, discrimination and HIV/AIDS in Latin America and the Caribbean. Washington, D.C.: InterAmerican Development Bank; 2003.

22. Rao Gupta G. Vulnerability and resilience: gender and HIV/AIDS in Latin America and the Caribbean. Washington, D.C.: InterAmerican Development Bank; 2003.

23. Moatti JP, Souville M, Obadia Y, Morina M, Sebbah R, Gamby T, et al. Ethical dilemmas in care for HIV infection among French general practitioners. Health Policy. 1995;31(3): 197210.

24. Merrill JM, Laux LF, Thornby JI. Why doctors have difficulty with sex histories. South African Med J. 1990;83(6):613-7.

25. Ryan JG, Aday LA, Hansel NK, Oser GT, Clasen ME. Family physician attitudes about HIV screening. J Acquir Immune Defic Syndr. 1992;5(8):835-40.

26. Wickramasuriya TV. Attitudes of medical students toward the acquired immune deficiency syndrome (AIDS). West Indian Med J. 1995; 44(1):7-10.

27. Green M, Hoffman IF, Brathwaite A, Wedderburn M, Figueroa P, Behets F, et al. Improving sexually transmitted disease management in the private sector: the Jamaica experience. AIDS. 1998;12 (suppl 2):S67-S72.

Manuscript received 30 December 2003. Accepted for publication 24 August 2004.
RESUMEN

\section{Estigma, discriminación} y conocimientos sobre el VIH/sida entre los médicos en Barbados
Objetivos. Dilucidar el alcance de los conocimientos prácticos que tienen los médicos de Barbados sobre el VIH y el sida y su actitud hacia las personas que padecen la enfermedad.

Métodos. En el año 2000 la Asociación de Médicos Generales de Barbados llevó a cabo una encuesta para evaluar las opiniones de los socios en torno a asuntos relacionados con el VIH y el sida. Durante un período de dos meses se entrevistó a 203 médicos (76\% de los que ejercen en el país). En la encuesta se incluyeron tanto médicos del sector público como de consultorios privados. Las entrevistas fueron individuales y versaron sobre sus actitudes hacia la orientación de los pacientes, conocimientos prácticos, nociones de prácticas inocuas, temor de exponerse al contagio, modo de ver las cuestiones éticas, experiencia con el tratamiento de pacientes con VIH o sida y formación médica continua en el campo de VIH/sida.

Resultados. Comparados con los médicos egresados más tarde, los graduados en 1984 o antes habían tratado a menos pacientes con infección por VIH o sida, tenían menos conocimientos de la enfermedad, se inclinaban más a administrar la prueba diagnóstica sin el consentimiento válido del paciente y era menos probable que hubieran asistido a algún curso de formación continua sobre el VIH y el sida. En general, tenían poco conocimiento del tratamiento indicado y $76 \%$ no se consideraban capacitados adecuadamente para orientar a los pacientes. Más de $80 \%$ dijeron que se sentían bastante seguros atendiendo a pacientes con infección por VIH o sida. De los encuestados, 95\% declararon que no entregarían los resultados diagnósticos a terceros sin el consentimiento del paciente, mientras que 33\% dijeron que administrarían la prueba detectora sin consentimiento a un paciente grave y $15 \%$, que lo harían si tuvieran que realizar una intervención invasora a un paciente de una población de alto riesgo, como las de homosexuales y trabajadores de la industria sexual. Solo 53\% de los médicos habían participado en programas de adiestramiento en el servicio entre 1995 y 1999.

Conclusiones. Es preciso que la formación médica en Barbados comprenda la atención de pacientes con infección por VIH o sida, incluidos todos los aspectos, tanto clínicos como afectivos. Para los médicos del sector público debe ser obligatorio asistir a ese tipo de adiestramiento; además, es necesario examinar los planes de estudio de las escuelas de medicina para cerciorarse de que sean completos y actualizados. 